\title{
Unilateral permission and prescriptive acquisition: a Scottish perspective.
}

\author{
ANDERSON, C.
}

2020

This is an Accepted Manuscript of an article accepted for publication in a revised form by Cambridge University Press in Legal Studies, https://www.cambridge.org/core/iournals/legal-studies. This version is free to view and download for private research and study only. Not for re-distribution or re-use. (c) The Society of Legal Scholars 2020. 


\section{Unilateral permission and prescriptive acquisition: Scottish perspective $^{1}$}

\section{Introduction}

Most legal systems, and certainly Scotland and England, have rules allowing a person who has possessed land without challenge, for an extended period of time, to acquire an unchallengeable right in the property. Suppose that I am in possession of someone else's land, occupying it as if it is my own property. There are several things that may happen. Either the owner will become aware of the fact of my possession, or will not. If the owner becomes aware, he or she may or may not attempt to remove me from the land, either by going to court or by taking some more direct action. Alternatively, the owner may ignore my presence, or may attempt to regularise my occupation, for example by agreeing with me a lease of the property. Another possibility is that the owner unilaterally grants me permission to continue in occupation of the land, until such time as the owner needs it. There are comprehensible reasons why this may happen. Perhaps the owner intends to develop the land, but the plans for development are not yet finalised, and so the owner is happy to allow me to continue on the land in the meantime. Alternatively, there may be some other reason.

The purpose of this paper is to consider the effect of such unilateral permission on acquisition of ownership by a period of possession. For consistency's sake, although terminology for this varies between different jurisdictions, the term 'prescriptive acquisition' will be used as a general term for acquisition of this kind. The effect of unilateral permission on prescriptive acquisition has received some attention recently in England. In this paper, we will consider the position in both England and Scotland, in the hope that it may be possible for each to learn from the other. At the very least, it is hoped that some external perspective on the treatment of these issues in each system may be productive of further discussion. In the course of the consideration of these issues, it will be suggested that the key question is whether parties' intentions are to be viewed objectively - based on what they say and do - or subjectively - based on their actual understandings.

\section{Unilateral permission and possession in English law}

\footnotetext{
${ }^{1}$ A version of this paper was delivered in the Property Law section of the Society of Legal Scholars conference held in September 2018 at Queen Mary University of London. Thanks are due to attendees of that section for very stimulating and useful comment and discussion. Errors, of course, remain the author's own.
} 
Before going any further than the specific question considered in this paper, some brief words are necessary about the operation of prescriptive acquisition in English law. ${ }^{2}$ There are in fact various devices by which an unchallengeable right may be acquired by a person acting, for a specified period of time, as if the right already exists. Thus, by the doctrine of the lost modern grant, long-term use will give rise to a presumption that it is based on a grant, made by the owner of the land, but which is now lost. ${ }^{3}$ Further, profits à prendre, easements and rights to light may be acquired by long-term enjoyment, in terms of sections 1 to 3 of the Prescription Act 1832 . This acquisition is barred by showing that 'the same was taken and enjoyed by some consent or agreement expressly made or given for that purpose by deed or writing.' Notwithstanding these words, though, it is settled that oral consent is sufficient to prevent the operation of prescription under the 1832 Act. The reason for this is that use with permission is not 'as of right', as required by section 5 of the 1832 Act. As was said in Tickle v Brown: ${ }^{4}$

asking leave from time to time within the forty or twenty years, breaks the continuity of the enjoyment as of right, because each asking of leave is an admission that, at that time, the asker had no right.

From the point of view of the present paper, it is interesting to note the implication here that permission given during the prescriptive period will interrupt prescription. It does not merely prevent prescription beginning to run. What it does not settle, however, is whether that permission may effectually be given unilaterally by the owner of the land.

Neither of these methods is in use for the acquisition of ownership, however. Focus here must turn to the doctrine of limitation. Our starting point is a distinctive feature of

\footnotetext{
${ }^{2}$ The following leaves out of account common law prescription, which requires it to be shown that the right claimed has been enjoyed since 1189. The difficulties in achieving this are sufficiently obvious that it is no surprise to find common law prescription little resorted to in practice. See R Megarry \& W Wade, The Law of Real Property (8th edn by C Harpum, S Bridge \& M Dixon, London, 2012) para 28-059.

${ }^{3}$ For an account, see R Megarry \& W Wade, The Law of Real Property (8th edn by C Harpum, S Bridge \& M Dixon, London, 2012) paras 28-062 - 28-065. If an outsider to the English system may say so, the lost modern grant doctrine is a most peculiar one. The lost modern grant may be entirely fictitious, and it is no objection that there was probably or definitely no such grant. The presumption can only be rebutted by showing that there was nobody who could lawfully have made the grant during the period in which it might have been made.

4 (1836) 111 ER 826 at 831, 4 Ad \& E 369 and 383 (Lord Denman CJ). See also Gardner v Hodgson's Kingston Brewery Co Ltd [1903] AC 229; Ward v Kirkland [1967] Ch 194; and discussion at R Megarry \& W Wade, The Law of Real Property (8th edn by C Harpum, S Bridge \& M Dixon, London, 2012) paras 28-075 - 28-076.
} 
English land law, namely the concept of relativity of title. In Ocean Estates Ltd $v$ Pinder, ${ }^{5}$ Lord Diplock put it in this way:

there is no such concept as an 'absolute' title. Where questions of title to land arise in litigation the court is concerned only with the relative strengths of the titles proved by the rival claimants. If party A can prove a better title than party $\mathrm{B}$ he is entitled to succeed notwithstanding that $\mathrm{C}$ may have a better title than $\mathrm{A}$, if $\mathrm{C}$ is neither a party to the action nor a person by whose authority B is in possession or occupation of the land.

Such a title may be acquired simply by taking possession of the land, possession being seen as a 'root of title'. ${ }^{6}$ Even a squatter has such a title. Thus, suppose that you have a title to an area of land in England. I dispossess you of it. I then have a title to the land that I can enforce against anyone except you (or someone deriving right from you). There are therefore two titles to the land, but one (yours) is relatively superior to the other.

The ability of the prior title holder to enforce his or her right is, however, timelimited. How this works differs somewhat depending on whether the land is registered. In the case of unregistered land, the limitation period is twelve years, ${ }^{7}$ on the expiration of which the prior title is extinguished. ${ }^{8}$ In the case of registered land, a person who is in adverse possession for ten years may apply for registration as proprietor. If objection is made by the owner, the application must normally be rejected, but another application may be made after a further two years' adverse possession. ${ }^{9}$

\section{(b) Smith v Molyneaux}

We are now in a position to return to the question posed above, whether unilateral permission interrupts prescriptive acquisition. This issue arose in the recent case of Smith v Molyneaux. ${ }^{10}$ The case involved an area of land on the island of Tortola, in the British Virgin Islands. This land had been acquired by Alexander Smith in about 1920 with a view to developing it. At

\footnotetext{
${ }^{5}$ [1969] 2 AC 19, 25.

${ }^{6}$ See e.g. R Megarry \& W Wade, The Law of Real Property (8th edn by C Harpum, S Bridge \& M Dixon, London, 2012) para 4-007.

${ }^{7}$ Limitation Act 1980, s. 15.

${ }^{8}$ Limitation Act 1980, s. 17.

${ }^{9}$ Land Registration Act 2002, s. 97 and sch. 6.

${ }^{10}$ [2016] UKPC 35; [2017] 1 P \& CR 7.
} 
this point, a woman called Victoria Cameron was living on it. Smith allowed her to remain on the property under an informal arrangement pending development, which never in fact happened in Alexander Smith's lifetime. Molyneaux moved in around 1956, and married Cameron in 1963. They cohabited in a shack on the land until her death in 1992, which terminated the licence to occupy. Nonetheless, Molyneaux continued to live there.

Under the relevant law, ${ }^{11}$ a person could acquire ownership of land by 'peaceable, open and uninterrupted possession without the permission of any person lawfully entitled to such possession for a period of 20 years.' More importantly, the right of the owner of land to recover possession was subject to a limitation period of twelve years, along the English model. ${ }^{12}$ The plaintiffs, members of Alexander Smith's family, served on Molyneaux a notice to quit in 2006, and again in 2007, as they now wished to develop the property. Molyneaux refused to vacate, asserting that he had acquired a title which, owing to the operation of limitation, ceased to be challengeable by the plaintiffs in 2004, in other words twelve years from Cameron's death.

The question then was whether Molyneaux had had sufficient adverse possession during the twelve year period for limitation to operate. At first instance, it was held that he had not. This decision was reversed on appeal, but on a further appeal to the Privy Council the first instance decision was restored. Fundamental to this outcome was the fact that, as the judge at first instance found, the Smiths had told Molyneaux in conversation that he could stay on the land until it was needed for development. This unilateral permission, it was held, rendered Molyneaux's occupation as being by licence, and so interrupted the limitation period. This decision has been the subject of some criticism. To understand why, we must take some time to consider the requirements for adverse possession in English law and how they have developed. Of particular importance here is the leading case of $J$ A Pye (Oxford) Ltd $v$ Graham. ${ }^{13}$ However, there is an earlier line of authority that influenced the decision in Smith v Molyneaux, but is to some extent inconsistent with the decision in Pye. This earlier line of authority will be considered first.

\section{(c) A heretical view}

\footnotetext{
${ }^{11}$ Registered Land Act (BVI), s. 135(1).

12 Limitation Act (BVI), s. 6.

13 [2002] UKHL 30; [2003] 1 AC 419; [2002] 3 WLR 221; [2002] 3 All ER 865.
} 
There is nothing in any way unintelligible in the Smiths' actions in allowing Molyneaux to remain in occupation following his wife's death. Nor are they open to the criticism of being negligent in the defence of their rights, which is one of the usual justifications for prescriptive acquisition of rights. On the contrary, where a person owns land for which he or she has no present plans, but for which there are future development plans, and which is presently occupied in a way that is not objectionable to the owner, it is perfectly reasonable to allow the occupier to continue on the property. There was, presumably, nothing in the manner of Molyneaux's occupation that was inconsistent with the Smiths' plans and, indeed, there is a line of authority (subsequently denounced, as we shall see below, as 'heresy') to the effect that the consistency of Molyneaux's use with the Smiths' plans would be enough of itself to exclude adverse possession.

For example, in Leigh $v$ Jack, ${ }^{14}$ the defendant had acquired plots of land to the north and south of an intended street. Both plots were stated in the deeds to be bounded by the street, and so included no part of the street itself. Nonetheless, the defendant did make use of this strip of land. On the facts, there was held to be no adverse possession. For present purposes, the importance of this case is an observation by Bramwell $\mathrm{LJ}$ :

in order to defeat a title by dispossessing the former owner, acts must be done which are inconsistent with his enjoyment of the soil for the purposes for which he intended to use it. ${ }^{15}$

No such acts had been carried out here, as the land could still be turned into a street. On similar facts in Wallis's Cayton Bay Holiday Camp Ltd $v$ Shell-Mex and BP Ltd, ${ }^{16}$ occupation of an area intended for future development as a road was held not to amount to adverse possession. Indeed, the court here went further, and held an implied licence to exist in favour of the occupiers.

The facts of BP Properties Ltd v Buckler ${ }^{17}$ bore some similarity to those in Smith $v$ Molyneaux. In this case, a lease was terminated for non-payment of rent. An order for possession was granted in 1955, but the landlord did not enforce this, apparently on compassionate grounds arising from the medical condition of the defendant's mother. A

\footnotetext{
14 (1879) 5 Ex D 264.

${ }^{15}$ (1879) 5 Ex D 264, 273.

${ }^{16}$ [1975] QB 94; [1974] 3 WLR 387; [1974] 3 All ER 575.

17 (1988) 55 P \& CR 337.
} 
subsequent possession order, granted in 1962, was also not enforced. Further, more determined, efforts to oust the defendant's family began in 1974. Media criticism led to the owners dropping these efforts, and instead sending a letter to the defendant's mother, giving her permission to stay in the house for life. She did not expressly accept or reject this. It was held that there was no adverse possession, at least partly on the basis that possession is not adverse if it is consistent with the intentions of the holder of the paper title, but also on the basis that the unilateral permission prevented the possession being adverse.

(d) Pye v Graham

The decision in BP Properties Ltd v Buckler obviously gives strong support to the Smiths' position, and indeed it was expressly followed in Smith $v$ Molyneaux. The former decision has not, however, escaped criticism. ${ }^{18}$ The fundamental difficulty with it and the other cases referred to in the previous section is that they focus, not on what the possessor is doing with the land, but on the state of mind of the owner.

In the leading case of $J$ A Pye (Oxford) Ltd $v$ Graham, ${ }^{19}$ this point was directly addressed in the House of Lords. In that case, the plaintiffs were owners of an area of land. They granted the defendants a grazing licence for 1983, but refused to extend this as they had plans to develop the land. The defendants continued in occupation nonetheless, having made attempts to arrange a formal licence without obtaining any response. At all times, the defendants were willing to pay for their occupation if called upon to do so. This case, then, was very similar in its facts to those of Smith $v$ Molyneaux, but without the element of unilateral permission. Lord Browne-Wilkinson, with whom the other judges concurred, said:

It is hard to see how the intentions of the paper title owner (unless known to the squatter) can affect the intention of the squatter to possess the land. ${ }^{20}$

\footnotetext{
${ }^{18}$ See below.

${ }^{19}$ [2002] UKHL 30; [2003] 1 AC 419; [2002] 3 WLR 221; [2002] 3 All ER 865. For previous intimations of this approach, see e.g. Powell v McFarlane (1979) 38 P \& CR 452; Buckinghamshire CC v Moran [1990] Ch 623; [1989] 3 WLR 152; [1989] 2 All ER 225; Ramnarace v Lutchman [2001] UKPC 25; [2001] 1 WLR 1651; [2002] 1 P\&CR 28.

${ }^{20}$ At para 32.
} 
Lord Bramwell's dictum in Leigh v Jack was denounced as 'heretical and wrong', ${ }^{21}$ and the defendants were held to have acquired a title by adverse possession. Even the defendants' willingness to pay for their occupation was no barrier to acquisition. ${ }^{22}$

\section{(e) Criticisms of Smith v Molyneaux}

The decision in Smith v Molyneaux has been criticised on two main grounds.

First, it has been said that the decision relies uncritically on Buckler, which has itself been criticised and which (it is said) places excessive weight on the intentions of the holder of the paper title and too little on the actual intentions of the occupier of the property. ${ }^{23}$

Second, Smith v Molyneaux has been criticised for relying on an objective test of possessory intention. An objective test:

is not based on what the actual parties understood, or on finding evidence that a permission was communicated and understood by non-verbal means. Rather, the test involves the implication of a permission from the circumstances of the case, regardless of what the parties might have understood, judged from the viewpoint of a hypothetical reasonable bystander. The instability of the boundary between this formulation of the test and the discredited 'implied licence heresy' is obvious. ${ }^{24}$

The alternative approach is a subjective approach, where there is express or implied communication 'intended to be understood, and understood, as a permission to render lawful what would otherwise be a trespass'. ${ }^{25}$

No position is however taken on those arguments here, as far as English law is concerned, although reference will be made to them below. Rather, the remainder of this paper is concerned with the approach of Scots law to the issue raised in Smith v Molyneaux.

\footnotetext{
${ }^{21}$ At para 45.

${ }^{22}$ At para 46. Compare, though, the later case of Colin Dawson Windows Ltd v King's Lynn and West Norfolk $B C$ [2005] EWCA Civ 9; [2005] 2 P\&CR 19. Compare also the South African case Minister van Landbou v Sonnendecker 1979 (2) SA 944. The decision is in Afrikaans, but there is a short summary at C G van der Merwe, 'Ownership' 1979 Annual Survey of South African Law 222.

${ }^{23}$ O Radley-Gardner, 'Foisted Permission and Adverse Possession' (2017) 133 LQR 214 at p. 216; R Hickey, 'The Effect of Supervening Permission on Adverse Possession' (2017) 81 Conv 223 at pp. 226-228.

${ }^{24}$ O Radley-Gardner, 'Foisted Permission and Adverse Possession' (2017) 133 LQR 214 at p. 215. See also R Hickey, 'The Effect of Supervening Permission on Adverse Possession' (2017) 81 Conv 223 at p. 228.

${ }^{25}$ O Radley-Gardner, 'Foisted Permission and Adverse Possession' (2017) 133 LQR 214 at p. 215.
} 


\section{A Scottish approach}

Let us now consider the approach of Scots law to this issue. Before going further, though, there are important differences between Scots and English law in this area that must be noted. We have already seen that English law adopts the approach whereby title to land is relative rather than absolute. Robin Hickey applies this principle to the present problem in the following manner:

[The] orthodox view is that [the adverse possessor] acquires a fee simple estate from the inception of her possession, albeit one relatively inferior to the continuing title of the paper owner. Accordingly, to accept the argument that supervening permission, unilaterally granted, operates to bring adverse possession to an end, we must accept the proposition that the grant of such a licence is sufficient to divest the possessor of her common law fee simple. This proposition is not self-evident. ${ }^{26}$

In Scots law, following the Civilian approach, the rights of the parties are conceptualised quite differently. With us, despite some occasional attempts to strike a different path, ${ }^{27}$ ownership is an absolute right, not a relative one. ${ }^{28}$ If I am owner of the land, then it follows that you cannot be, unless we have a shared right of common or joint ownership. ${ }^{29}$ The possessor is merely that: a possessor. Following the Roman model, 'ownership has nothing in common with possession'. ${ }^{30}$ A possessor certainly has some rights by virtue of that possession, not least the right not to be dispossessed without consent or an order of the court, but that is in no sense conceptualised as any kind of ownership. This is quite fundamentally different from what we have seen to be the position of English law.

This difference may well affect how we view the question of unilateral permission. It perhaps implies that, in Scots law, possession will be more easily lost. We shall see as we go along. However, there is a further consequence of this different conceptualisation of possession, namely that a system of limitation would simply not work in Scots law. As

\footnotetext{
${ }^{26}$ R Hickey, 'The Effect of Supervening Permission on Adverse Possession' (2017) 81 Conv 223, 229.

${ }^{27}$ Heritable Reversionary Company Ltd v Millar (1892) 19 R (HL) 43; Sharp v Thomson 1997 SC (HL) 66.

${ }^{28}$ Burnett's Trustee v Grainger [2004] UKHL 8, 2004 SC (HL) 19.

${ }^{29}$ These concepts differ from each other in a manner that need not detain us here. In brief, common ownership is the normal situation of shared ownership, where each co-owner has a separate share that may be separately contracted with. Joint ownership is a specialised situation in which there are no separate or separable shares, and is the manner in which trustees hold. For a fuller account, see K G C Reid, The Law of Property in Scotland (1996) paras 17-40.

${ }^{30}$ D.41.2.12.1.
} 
Hickey indicates in the passage quoted above, the theory of the English law of adverse possession is that both the holder of the paper title and the current possessor are owners, but the right of the former is relatively superior to that of the latter. The current possessor can enforce that right against anyone except someone with a relatively superior right, until the expiry of the limitation period cuts off any challenge by such a person. In Scots law, by contrast, a limitation period on ownership of land would simply leave nobody with any kind of enforceable ownership right. The land would be left in a sort of legal limbo.

Instead, in Scots law, acquisition is by positive prescription. In a system of positive prescription, the acquirer has no right of ownership until the requisite period of possession is complete. Until then, the acquirer is merely a possessor, with no rights in the property beyond what that implies. In Buckinghamshire CC v Moran, ${ }^{31}$ Nourse LJ commented on this distinction:

The Scots and continental systems, more faithful to the Roman law, have opted for prescription, a doctrine founded on the fiction that the land has been granted to the squatter. In England, prescription, although a shoot well favoured by the common law, was stunted in its lateral growth by the statutes of limitation...

In fact, in Scots law, this grant of the land to the squatter is an actual grant, albeit one that has been granted by a non-owner. Unusually, in Scots law, it is necessary first to register in the Land Register ${ }^{32}$ an apparent conveyance of the land before prescription can run. Without registration in my favour, it does not matter how long I possess the land. I could possess for a hundred years, and would nonetheless acquire no ownership of the land. It is only once a title has entered the Land Register in my name that I can acquire by positive prescription, by then possessing the land 'for a continuous period of ten years openly, peaceably and without any judicial interruption' on the basis of that title. ${ }^{33}$ It does not matter for these purposes that the conveyance on which the registration is based was one granted by a non-owner (known as an a non domino disposition). Indeed, a conveyance granted by an owner does not need positive prescription to make it good. All that is required of this conveyance (known as the

\footnotetext{
${ }^{31}$ [1990] Ch 623, 644.

${ }^{32}$ Formerly, this could be done by recording the conveyance in the older Register of Sasines instead. However, the registration of a conveyance in the Register of Sasines is no longer competent: Land Registration etc (Scotland) Act 2012, s. 48(1)(a).

${ }^{33}$ Prescription and Limitation (Scotland) Act 1973, s. 1(1). The possibility of the registration of purely speculative a non domino conveyances is, however, seriously restricted by the terms of the Land Registration etc (Scotland) Act 2012, s. 43.
} 
'foundation writ') is that it is ex facie valid and is not forged. ${ }^{34}$ It may be that there are criticisms that could be aimed at this system. It does, however, have the great merit that, while the property registers cannot be relied on with complete certainty, it can at least be known that no person who has not at some point entered the register can possibly be owner of any given land. More to the point, for present purposes, if the defendant in Smith $v$ Molyneaux had been required to register in a property register before his possession could give him ownership, that would have been a much clearer indicator of his intentions. At the same time, even in Scotland, certain other rights can be prescriptively acquired without registration, ${ }^{35}$ so the same issue could still arise north of the border.

That said, even though Scots property law has experienced much more Roman influence than English property law, there are common characteristics in the concept of possession in both jurisdictions. Indeed, this was noted by Lord Browne-Wilkinson in Pye:

...there has always, both in Roman law and in common law, been a requirement to show an intention to possess in addition to objective acts of physical possession. Such an intention may be, and frequently is, deduced from the physical acts themselves. But there is no doubt in my judgment that there are two separate elements in legal possession...It is not the nature of the acts which A does but the intention with which he does them which determines whether or not he is in possession. ${ }^{36}$

In Scots law, too, possession has a physical and a mental element, namely control of the property and the intention to hold on one's own behalf. ${ }^{37}$ Equally, in Scotland as in England, nobody can impose on another an intention the latter does not have. ${ }^{38}$ Nonetheless, there is good reason to think that a Scottish court would take a similar view to the board in Smith, and that the criticisms aimed at it would not find favour in Scotland.

\footnotetext{
${ }^{34}$ Prescription and Limitation (Scotland) Act 1973, s. 1(2). Where the foundation writ is registered in the Land Register, it is enough simply that the person registered as proprietor is unaware of any forgery.

${ }^{35}$ The most important example of this is positive servitudes, prescriptive creation of which is governed by the Prescription and Limitation (Scotland) Act 1973, s. 3.

${ }^{36}$ At para 40.

${ }^{37}$ K G C Reid, The Law of Property in Scotland (1996) paras 117-125.

${ }^{38}$ This is a minor exception to this, not relevant to the issue under consideration. This is the case where goods belonging to one person are in the custody of a third party. Possession of those goods may be transferred to another simply by giving notice to the third party custodier. There is no reason for the custodier to accept the change of possession. See C Anderson, 'Delivery of goods in the custody of a third party: operation and basis' (2015) 19 Edin LR 165.
} 
Before going further, it is necessary to make a distinction. In Smith v Molyneaux, the defendant's occupation of the property appears to have been initially lawful. He occupied along with his wife, who had a licence to occupy the property. It was only on her death that that changed. This is different from the situation where land is occupied by an out-and-out squatter, who moves onto land without ever having had a right to be there. As this distinction may make a difference to the conclusions reached, these two situations will be addressed separately.

\section{(a) Possession initially lawful}

In Smith v Molyneaux, Mr Molyneaux's occupation of the property was initially lawful. From a Scots point of view, this is a significant point. We have already seen that the Scots law of possession draws heavily on the Roman sources. We shall see later what Scots law has to say about this point, but for now it is interesting to note the Roman law maxim: nemo sibi causam suam possessionis mutare potest, or 'nobody can, by himself, change the basis of his possession' (referred to from here on as 'the nemo mutare potest rule'). In other words, having begun to possess property on one basis, one could not unilaterally change to possessing on a different basis. ${ }^{39}$ One who holds as a tenant cannot unilaterally change the basis of that holding such that he can acquire ownership by prescriptive possession. ${ }^{40}$

This bar on changing the basis of possession was not a universal rule. From the texts, we can identify several exceptions. First, a person who had lost possession could subsequently reacquire it on a different ground. ${ }^{41} \mathrm{We}$ are concerned here with the case where the possessor has physically left the property, and then later re-entered on a different basis. ${ }^{42}$

Second, where the basis of an existing possession is renewed, that is not considered to breach the rule. ${ }^{43}$ This is the case even where the existing basis for the possession has

\footnotetext{
${ }^{39}$ D.41.3.33.1. There is some doubt in the texts as to whether this is restricted to possessors stricto sensu, or whether it extends also to custodiers generally. Julian (D.41.5.2.1) held that tenants, depositees or borrowers (who did not, in Roman law, possess) could not unilaterally make themselves possessors in order to acquire ownership by usucapio, and Papinian (D.5.4.10) appears to have considered the rule at least potentially to have applied to a negotiorum gestor seeking to possess as heir. By contrast, Paul says (D.41.2.3.19-20) that someone who holds on the basis of deposit or commodatum, to whom the owner then conveys the property, is not considered to change the ground of his possession, because he did not previously possess at all. (A commodatum is a loan for use, with the same item returned. It is to be contrasted with a mutuum, a loan for consumption, in which an equivalent is to be returned. In a mutuum, the borrower becomes owner, and so does possess).

${ }^{40}$ C.7.32.5 (undated, but under Diocletian).

${ }^{41}$ D.41.2.19.1 (Marcellus), G.2.59.

${ }^{42}$ L Barnard, 'Usurpation of Title - A Note on Voet Commentarius ad Pandectas 41.2.13' (1988) 105 SALJ 114.

${ }^{43}$ D.43.26.5 (Pomponius).
} 
expired, for example where a lease having expired, but the tenant having remained in occupation, ${ }^{44}$ a new lease is then granted. In the interim, the basis for the occupation remains the same. It is no objection that there is at that point no existing lease, for the question of possession is not determined by what people's rights are. It is about what they do and the intention with which they do it. A person occupies as a tenant if he or she occupies in the manner of a tenant, regardless of whether a valid lease in fact exists.

Third, however, according to at least one text, an imperial decision of AD 293, ${ }^{45}$ a person who has occupied on a subordinate basis, but who is then proved to be owner, may then possess as owner. The decision concerns a case of a lease being granted to a person who later proves to be owner. The tenant will then possess as owner and, what is more, must be treated as always having possessed as owner rather than having occupied as tenant, to avoid a breach of the nemo mutare potest rule.

The fourth case is the most significant for present purposes. This is the case where, although a person has begun to hold on one basis, some genuinely new basis supervenes. The best-known example of this is the form of transfer of possession of property that came, in the Middle Ages, to be known as constitutum possessorium. ${ }^{46}$ Suppose that I am owner of an area of land, and in possession of that land. I enter into an agreement with you to the effect that I will sell the land to you, but remain in occupation as your tenant. In other words, this is a sale and lease-back arrangement. Even though I do not physically leave the property, I nonetheless effectually transfer possession to you. The jurist Celsus explained in this way how this transfer was effective, despite the existence of the nemo mutare potest rule:

What I possess in my own name I can possess in that of another; and I do not thereby change the ground of my possession, but rather do I cease to possess and make the other person possessor through my agency. For it is one thing to possess and another to possess on someone else's behalf; he is the possessor in whose name a thing is possessed; the procurator simply provides the agency of another's possession. ${ }^{47}$

\footnotetext{
${ }^{44}$ A tenant was not considered in Roman law to possess, not having the protection of the possessory interdicts. In Scots law takes a somewhat broader view of the kinds of holders who can possess, and a tenant is considered a possessor.

${ }^{45}$ C.4.65.23.

${ }^{46}$ Reid, Property para 623 (Gordon).

${ }^{47}$ D.41.2.18pr.
} 
In other words, by this arrangement, I give up my original possession. My continuing acts of possession are now carried out on your behalf, and so you acquire possession through them.

Although constitutum possessorium is the most prominent example of this kind of change of the ground on which property is held, it is not the only one in the Roman texts. For example, suppose that I am in possession of another person's property, and then the owner sells or gifts it to me, or else in court proceedings over the property I accept an award against me of the value of the property, ${ }^{48}$ I then begin to possess as owner. ${ }^{49}$ Similarly, if I possess someone else's property as if I am owner, but then enter into an agreement with the actual owner that I will possess on the basis of precarium, ${ }^{50}$ I change the ground of my possession. ${ }^{51}$ Again, while the nemo mutare potest rule prevents a wife prevents a wife acquiring ownership of a gift from her husband by usucapio (prescriptive acquisition), a gift between spouses being ineffective, ${ }^{52}$ she can nonetheless acquire in this way if he leaves the item with her after their divorce. ${ }^{53}$

What is the basis for this exception to the nemo mutare potest rule? According to at least one writer, the purpose is to impose a requirement of good faith: Aspiranten te goeder trouw hebben van de regel niets te vrezen ('Good faith acquirers have nothing to fear from the rule'). ${ }^{54}$ All of the examples referred to above involve the coming into existence of some genuinely new legal basis for the holding of the property, although the Dutch jurist Voet used these texts as the basis for a more expansive view, that 'some fresh fact, whether genuine or fictitious, must come into play' (emphasis added). ${ }^{55}$ It is far from clear, it must be said, that the reference to fictitious facts is justified by the texts Voet refers to. Somewhat later, the French jurist Pothier gave a much stricter interpretation of the nemo mutare potest rule:

\footnotetext{
${ }^{48}$ In classical Roman procedure, in an action for vindication of property, the judge would not require the property itself to be restored to its owner. Instead, the possessor had the option of paying its value. As Ulpian points out (D.41.4.3), payment of the value on this basis is akin to a purchase, so by accepting this award I am in effect purchasing the property.

${ }^{49}$ D.41.4.2.21.

${ }^{50}$ A precarium was a revocable licence to occupy land.

${ }^{51}$ D.43.26.22pr; D.43.26.6.3.

${ }^{52}$ D.24.1.1.

${ }^{53}$ D.41.6.1.2.

${ }^{54}$ F B J Wubbe, 'Nemo sibi causam possessionis mutare potest' in J E Spruit \& M van de Vrugt eds, Brocardica in honorem G C J J van den Bergh: 22 Studies over Oude Rechtsspreuken (Kluwer: Deventer 1987), at p. 130. Good faith must be understood here as meaning openness rather than honesty.

55 J Voet, The Selective Voet, Being the Commentary on the Pandects (P Gane ed and trans, Durban, $1955-$ 1957), 41.2.13. For criticism of Voet's position, see L Barnard, 'Usurpation of Title - A Note on Voet Commentarius ad Pandectas 41.2.13' (1988) 105 SALJ 114.
} 
s'il parait qu'une chose que je possède m'ait été donné à la posséder à titre d'engagement, ayant commencé à la posséder à ce titre, quelque déclaration que je fasse, quelque long temps qui sécoule, tant qu'il ne paraîtra pas d'autre titre survenu depuis moi, mes héritiers et les héritiers de mes héritiers in infinitum continueront toujours à la posséder à ce titre d'engagement. ${ }^{56}$

Savigny takes a more moderate approach, while still requiring some objective indication of the changed intention: 'if a tenant disclaims his landlord's title, he actually changes the conductionis causa into a dejectionis causa, and thereby acquires a true possessio. ${ }^{57}$ The texts he cites as authority for this are both concerned with the case where a tenant refuses entry to a landlord or to a purchaser from the landlord. ${ }^{58}$

There is also a practical point, expressed in an imperial decision of AD 365. If we allow a non-owning occupier to begin prescriptive acquisition by a private change of intention, the risk is that 'owners will either have to lose what they have leased out or perhaps remove tenants who are useful to them, or publicly declare their ownership every year' ${ }^{59}$

Whatever view is taken of this, there is a fundamental point here about the nature of the mental element of possession. Let it be granted that there are two distinct, free-standing requirements for possession, the physical and the mental. That does not alter the fact that the mental can only be known through the physical; that is, we can only know what a person intends through what that person says and does. It has been said, fairly enough, if with a hint of hyperbole, that it is 'dangerous and alien to reality' to 'make the intention supreme, even where it is unexpressed and undemonstrable' ${ }^{60}$ Added to this, there is a further consideration. In a case in which matters are arranged as informally as in Smith v Molyneaux, there is every likelihood that the parties had no specific, conscious intention at all. From that point of view, there must sometimes be a deeming of what the parties intend, and this can only be done on the basis of what they say and do.

There ought to be nothing especially controversial about this. We are used to the idea of judging a person's intentions by some external standard. In the law of contract, for

\footnotetext{
${ }^{56} \mathrm{R}$ J Pothier, Traité de la possession, para 31 ('if it appears that a thing that I possess has been given to me to possess on a contractual basis, having begun to possess it on that basis, whatever declaration I may make, however long a time it lasts, as long as no other title occurs, my heirs and my heirs' heirs will continue in infinitum to possess on that contractual basis.')

${ }^{57}$ F K von Savigny, Von Savigny's Treatise on Possession 6th edn (E Perry trans, 1848) 49.

${ }^{58}$ D.43.16.12 (Marcellus); D.43.16.18pr (Papinian).

${ }^{59}$ C.7.39.2.1.

${ }^{60}$ F Pringsheim, 'Animus in Roman Law' (1933) 49 LQR 43, 48.
} 
example, we say that contracts 'cannot be arranged by what people think in their inmost minds', but rather 'according to what people say' ${ }^{61}$ Likewise, section 18 of the Sale of Goods Act 1979 presumes parties to a sale to have intentions that they almost certainly do not have, according to the surrounding circumstances. At the heart of any question about intention lies a tension between objective and subjective views: to what extent should the law allow someone to claim to have an intention that has not been objectively manifested?

The problem this approach poses for the prescriptive acquirer on facts such as those in Smith $v$ Molyneaux and Pye v Graham is obvious. One commentator has gone so far as to say: 'I am certain that, on this basis, the action of the plaintiffs in Pye v Graham could not have failed to succeed. ${ }^{62}$ It is not necessary for present purposes to reach a view on whether an argument based on the nemo mutare potest rule would have any chance of success in England. However, it is instructive to note that the Court of Appeal in Pye used reasoning that was very similar to the nemo mutare potest rule, in suggesting that the fact of the nature and degree of use continued unchanged after the original licence ended was suggestive of the necessary change of possessory intention being absent. ${ }^{63}$ In the House of Lords, this approach was rejected, not as being wrong in law, but as not being justified by the evidence: 'the Grahams repeatedly did things on the disputed land which they would have had no right to do under the old grazing agreement even if it had still been in force. ${ }^{64}$ It is also interesting to note that Blackstone gave the nemo mutare potest rule, or something very like it, as the law in England:

because the tenant being once in by a lawful title, the law (which presumes no wrong in any man) will suppose him to continue upon a title equally lawful; unless the owner of the land by some public and avowed act, such as entry is, will declare his continuance to be tortious, or, in common language, wrongful. ${ }^{65}$

These considerations suggest that there may be at least some hint of the nemo mutare potest rule in English law.

\footnotetext{
${ }^{61}$ Muirhead \& Turnbull v Dickson (1905) 7 F 686, 694 (Lord President).

${ }^{62}$ W J Zwalve, 'What a Condition Would Men Be In! (Three Cases on Prescription and Adverse Possession)' (2005) 16 Stell LR 336, 345.

${ }^{63}$ [2001] Ch 804 at 818-819.

64 [2002] UKHL 30, [2003] 1 AC 419, [2002] 3 WLR 221, [2002] 3 All ER 865 at para 58.

${ }^{65}$ Blackstone, Commentaries on the Laws of England II.150.
} 
After this lengthy background discussion, we must now come to Scots law. Although the modern literature has largely overlooked the rule, ${ }^{66}$ there is no doubt that it was received in Scotland. The institutional writer ${ }^{67}$ Stair said:

Possession...is ascribable only to that title by which it did begin, in prejudice of him from whom the possession was acquired, and to whom it must be restored, notwithstanding any other right in the possessor, to which he might ascribe it, and which, after he had quit the possession, might recover it ${ }^{68}$

The nemo mutare potest rule has also made its appearance in case law, though rarely directly. Harper's Creditors $v$ Faulds ${ }^{69}$ is an exception. The particular point at issue is not of importance to the present discussion, so there is no need to go beyond a brief outline. Faulds, the defender in that case, was a bleacher. When Harper became bankrupt, Faulds had in his custody linen for bleaching, which he claimed to be entitled to retain until he was paid both the contractual price for his bleaching services and also other debts owed to him by Harper. In other words, the question was whether Faulds' right to retain the linen was a special lien or a general lien. The majority held that the lien was a special one, restricted to the contract price. $^{70}$ The importance of the case for us is that one of the judges in the majority, Lord Dreghorn, expressly founded his opinion on the nemo potest mutare rule:

'Nemo potest mutare suam possessionem,' is a rule admitted in our law, and unless something be done to alter the possession, it must remain as at first... ${ }^{71}$

\footnotetext{
${ }^{66}$ See e.g. K G C Reid, The Law of Property in Scotland (1996). Professor Reid's treatment of the mental element of possession at paras 123-125 makes no mention of the nemo mutare potest rule. The same is true of the treatments of possession in W M Gordon \& S Wortley, Scottish Land Law 3rd edn (vol 1, 2009) paras 14-02 - 14-10 and D L Carey Miller with D Irvine, Corporeal Moveables in Scots Law 2nd edn (2005) paras 1.18 1.22 .

${ }^{67}$ The institutional writers are a number of writers of authority on Scots law, writing between the late seventeenth and early nineteenth centuries, of whom Viscount Stair is the most prominent. The second edition of his Institutions of the Law of Scotland, on which modern editions are based, was published in 1693. ${ }^{68}$ Stair, Institutions 2.1.27. See also Erskine, Institutes 2.1.30; Bankton, Institute 2.1.35. It should be noted here and in what follows that the same general ideas of possession apply in Scots law to both land and moveable property.

69 (1791) 2 Ross LC 708.

${ }^{70}$ For discussion of this general point, see Steven, Pledge and Lien, paras 10-111 - 10-122.

${ }^{71}$ At p. 716. In the same case, the Lord President did not use the phrase, but clearly also relied on the doctrine: 'The question then is, Whether the custodier can detain, not only for such expense; that is, whether he be entitled to take a more ample and beneficial possession than was stipulated at first?' (at p. 724). Later (at p. 726) he talks about 'converting the possession from a specific contract'.
} 
Lord Dreghorn's point here is that the linen was possessed by Faulds as a result of a specific bleaching contract, and to attribute that possession to other contracts would breach the nemo mutare potest rule.

Another case, of more direct relevance, is Houstoun $v$ Barr, ${ }^{72}$ which was a case where prescriptive acquisition was argued for. In that case, the defender was the owner of a house. The pursuer was the feudal superior of the house, which had been sold from lands belonging to the pursuer's predecessor in title. The defender had also for a long time been tenant of a field behind his house that belonged to the pursuer. Both the lease and the defender's ownership seem to have begun in 1860: it is a slight complication in the case that it is not clear which came first. The defender claimed to have acquired prescriptive title to an area of ground in front of the house, through which the field was reached. Various issues were considered, including the interpretation of the foundation writ: as noted above, in Scotland positive prescription must be based on a deed entered in the property register which is apparently valid and is capable in its terms of being interpreted to include the land in question. We are concerned, though, with the possession point. Lord Dundas, with whom all of the other judges concurred, said: ${ }^{73}$

during the whole period of alleged possession...the owners of the feu were tenants of the pursuer and his authors in certain fields immediately adjoining it...Now, it seems to me that all the alleged acts of possession were at least quite as referable to the right of tenancy of the fields as to that of ownership in the feu, and in that view cannot, I think, be pleaded by the defender as amounting to the adverse possession which would be necessary to exclude the pursuer, who might justly claim to regard his tenants' possession as his own. The possession, to avail the defender, must have been not only continuous, but clearly and unequivocally referable to his title of ownership.

\footnotetext{
721911 SC 134.

${ }^{73}$ At p. 143. In the quoted passage, the term 'feu' refers to estate of land held on feudal tenure. Such holdings were abolished by the Abolition of Feudal Tenure etc (Scotland) Act 2000 and replaced with absolute ownership, with which they were in any case functionally interchangeable for present purposes. That this abolition had to wait for the advent of the Scottish Parliament is a reminder of the difficulties of keeping a legal system up to date without a dedicated legislature. Before this, reforms of this kind which were necessary, but which were of a technical nature, struggled to find Parliamentary time. We often complain of an excess of legislation, but there can also be too little.
} 
In other words, having used the ground on a basis consistent with the pursuer's rights, the defender could not then attribute his use to a different basis without giving some clearer indication of his intentions.

Let us return for a moment, though, to Stair's account. The debt to Roman law in the institutional writers' accounts is clear and undisputable. However, there is an element in what Stair says that departs from the Roman rule to some extent. He says: 'Possession...is ascribable only to that title by which it did begin, in prejudice of him from whom the possession was acquired' (emphasis added). The institutional writers Erskine ${ }^{74}$ and Bankton $^{75}$ are to the same effect. Thus, this is not a general prohibition on unilaterally changing the basis of one's possession. Rather, one may simply not do so to the prejudice of the person from whom one acquired the property. In questions with other parties, one is free to attribute one's possession to whichever basis is most beneficial. Put this way, the matter almost seems a question of contract, that the presence of a contractual relationship between the parties governs the presumed intentions of the parties. Houstoun $v$ Barr could certainly be explained in that way. ${ }^{76}$ However, Harris $v$ Anderson,${ }^{77}$ cited by Stair as authority for his approach, suggests that this is not the basis of the rule. The report of the case is brief and the facts are obscure. However, it appears that Anderson's father was in possession of land that was claimed by Harris. Harris obtained a decree of ejection from the court, requiring Anderson's father to depart from the land. Harris gained possession of the land on this basis. This decree was subsequently set aside ${ }^{78}$ by the court in an action at the instance of Anderson. ${ }^{79}$ Anderson then sought to recover possession from Harris, who attempted to defend his possession on the basis of a prior title. The court held, however, that in a question with Anderson he could not found on any title other than that on the basis of which he took possession from Anderson, namely the decree of ejection that had been set aside. The argument for Harris was that, otherwise, 'decreets of repossession and redemption might always be eluded by alleging of forged titles aliunde et ex alia causa' ${ }^{80}$ Once he had restored

\footnotetext{
${ }^{74}$ Institutes 2.1.30.

${ }^{75}$ Institutes 2.1.35.

76 That interpretation would also have the benefit that it would be irrelevant whether lease or ownership came first. See also Earl of Morton v His Tenants (1625) Mor 15228

77 (1591) Mor 9217.

78 The term used is 'reduced'.

${ }^{79} \mathrm{We}$ are not told the basis on which the decree was reduced, but presumably there was some irregularity in the obtaining of it.

${ }^{80} \mathrm{We}$ see here the fear of forged and fraudulent titles that, a generation later, was to lead to the requirement for public recording of land transactions in the Register of Sasines. See the Registration Act 1617, an Act of the preUnion Scottish Parliament, which complains that 'by the fraudulent dealing of pairties who haveing annaliet thair Landis and ressauit gryit soumes of money thairfore Yet be thair uniust concealing of sum privat Right
} 
possession to Anderson, he could then raise a new action based on his alleged title. He would, however, then bear the burden of proving its validity. The point, though, is that there is no indication of any contract between the parties here. The rule then is perhaps best seen as a means of keeping litigation proceedings within a reasonable scope, by limiting the parties to matters directly raised by the dispute at hand, rather than allowing them to draw out or complicate proceedings with matters of more tangential significance.

An occupier who wants to change the basis of his or her possession will, therefore, need to do something that gives a clear indication of that fact. In the case of a tenant, David Johnston suggests that ceasing to pay rent will be enough:

where the acts are referable just as easily to a lease as to an assertion of ownership, there is no reason why the landlord should attempt to defend his own interests, since he has no ground to suspect that they are being challenged. That will change only if the tenant ceases to pay rent... [H] is failure to pay rent throughout the prescriptive period will prevent his possession from being referred to the lease. ${ }^{81}$

There is some room for doubt about this. There is nothing uncommon about a tenant failing to pay rent, and the mere fact of that failure cannot of itself be considered any kind of assertion of right. ${ }^{82}$ The case he cites as authority, Grant $v$ Grant, ${ }^{83}$ is not a typical one. The lease in question had been granted more than a hundred years previously, to a predecessor of the defender, and there was 'urged among the Lords' the 'inconvenience of producing an old latent tack, of which the heritor can have no suspicion, after 60 or 80 years'. All that this case can really be taken to show is that the application of the principle in Scots law is not as strict as is stated by Pothier, in the passage quoted above. However that may be, though, it may be supposed that acts more directly challenging the landlord's right would be enough. Examples would be physically excluding the landlord on termination of the lease or carrying out major alterations to the property, well beyond what is permitted by the lease.

\footnotetext{
formarlie made be thame rendereth subsequent alienatioun done for gryit soumes of money altogidder vnproffitable'.

${ }^{81}$ D Johnston, Prescription and Limitation 2nd edn (2012) para 18.25.

82 This is not to deny the practical advantages of Johnston's view. Many occupiers, holding on the basis of (usually) 999-year leases, granted in the nineteenth century, the original landlord of which is long forgotten and the current landlord unknown, have found the assumption very useful that it is enough for prescriptive acquisition simply to register a title and then fail to pay rent for ten years. The practical point has become less important since the conversion of most ultra-long leases to ownership by the Long Leases (Scotland) Act 2012. 83 (1677) Mor 10876.
} 
A final point may be made on this issue. To say that a person may not change the ground on which he or she possesses is to say that the basis of a person's holding of property is to be judged according to how that holding began. The practical difficulty with this, though, is that the dispute may arise long after the original basis of the holding has been forgotten. This was the situation in the English case, Gardner v Hodgson's Kingston Brewery Co Ltd. ${ }^{84}$ In that case, annual payments of 15 shillings had been made to allow access to the rear of a house through the courtyard of a neighbouring inn. This was held to prevent the use being as of right in terms of the Prescription Act 1832. A difficulty, though, was that, while the payments were shown to have been made consistently for more than forty years, the use itself had been made for around eighty years, and how it first came about that payment was made was long forgotten. It may have been that payment had in fact been made since the beginning of the disputed use, but this could not be shown. This point is certainly a formidable practical objection to the Pothier view of the nemo mutare potest rule, by which the possessor's intentions are permanently and immutably fixed from the beginning. The difficulty largely disappears, though, in the Scots view, by which the nemo mutare potest rule is rather a presumption of the parties' intentions. If a person has been making use of property, apparently as of right, for long enough that the origins of that use are forgotten, it seems reasonably safe to take the appearance of that use as a fair indicator of intention.

Where, then, does this leave an occupier in the position of Mr Molyneaux? As someone occupying on a gratuitous basis, Mr Molyneaux could obviously not withhold rent. This makes it more difficult for an occupier in his position to demonstrate a change of intentions, but it would not excuse him of the need. Simply put, it is suggested that the position in Scots law would be this: Mr Molyneaux began his occupation on the basis of the licence to occupy that had been granted to his wife, and which was by implication extended to him. The default position would be that his occupation would continue on the same basis. As nothing seems to have changed in the manner of his occupation, the Smiths had nothing to warn them of Molyneaux's changed intentions, and without this it would not be open to him to attribute his occupation to an intention to possess as if owner. This would be the case even though his actions might otherwise, considered in isolation, have been enough for prescriptive acquisition. The suggestion is therefore that, in Scots law, on the same facts, a claim to have possessed sufficiently for prescriptive acquisition would fail.

${ }^{84}[1903]$ AC 229. 


\section{(b) Possession not initially lawful}

Viewed in this way, the unilateral permission given in Smith $v$ Molyneaux seems something of a red herring. Molyneaux began his occupation on the basis of a permission to occupy. That at least seems the natural inference from the fact that no objection was made to his moving in with an acknowledged licensee. Although that licence had come to an end, the Scots view I would suggest is that his continued occupation would be considered still to be on that basis. As the manner of his occupation did not change in any way, as far as can be seen from the facts proved, the Smiths would in Scots law be entitled to treat him as still occupying on the same basis. At any rate, it seems unlikely that Molyneaux's possession would be viewed as sufficiently open for prescriptive acquisition to operate, as that requires acts 'which would indicate to a reasonably observant owner that someone was trying to occupy his property and so found a prescriptive title. ${ }^{85}$ If this case had arisen under Scots law, Molyneaux would have to have done something objectively attributable to his changed intention, perhaps by barring entry to the Smiths or carrying out acts on the land that were inconsistent with the original basis of his occupation. Without that, the Smiths would have had no reason to think that Molyneaux was attempting to acquire a prescriptive title.

From the point of view of Scots law, therefore, the unilateral permission only seems relevant as a consideration where the occupation of the land was originally without permission. The remainder of this paper will be directed at that situation.

Let us agree from the outset that the question of whether a person is in possession is decided by the acts and intentions of that person, not by anyone else's acts and intentions. If something that another person says or does is relevant at all, it is so only because of the light that that sheds on the aspiring possessor's acts and intentions.

Before going further, it is necessary to be clear that it can be no objection simply that the permission was not expressly accepted. Suppose that you own a field, and you unilaterally give me permission to occupy it. I then proceed to do so, in a manner consistent with your permission. It is natural to interpret my actions as a tacit acceptance of your permission. That, however, is not a necessary inference. It is entirely consistent with the facts described that I, in fact, had been intending to take up occupation of the field anyway, and if you hadn't given me permission I would have gone ahead regardless. Perhaps I believe that the field is in fact mine, or perhaps I was hoping that you wouldn't notice. The point is that my act of taking up

${ }^{85}$ Stevenson-Hamilton's Exrs v McStay (No 2) 2001 SLT 694. 
occupation of the field is capable of multiple interpretations. However, not knowing my inward intentions, you would be entitled to assume that I was taking up occupation on the basis of your permission.

As a point of principle, the same must be true of a permission given to me after I take up occupation: there is no logical reason to treat initial permission and later permission as different in principle, although the inferences we draw from the facts in a particular case may differ. Suppose that I am a sheep farmer. You own an area of land, neighbouring my farm, that is intended for development. In the meantime, seeing that it is becoming overgrown with grass, I allow my sheep to graze on it. I do not ask for your permission. However, when you find out, you tell me that you are happy for me to keep doing so until you are able to proceed with your development plans. Assuming that, in both cases, I have given no express acceptance of the permission, I am unable to see how it makes a difference whether I took up occupation before or after the permission was given. ${ }^{86}$ In both cases, a permission has been given, and this has been followed by usage that is consistent with that permission. In both cases, my actions are consistent with both an intention to use in accordance with that permission, and also an intention to use the property regardless of permission. It does not seem unreasonable to presume, in the absence of other evidence, that I intend to occupy lawfully and in accordance with your permission. Matters might be different if I use the land in a way that is inconsistent with your development plans. This is not, though, because your intentions are decisive of whether I possess or not, or of the basis on which I possess. Rather, it is because my actions then are more naturally attributable to an intention to act in your despite, and to possess for myself.

There seems, then, to be nothing inherently contrary to principle in giving effect to a unilateral permission in cases like Smith $v$ Molyneaux. There is little authority on the point in Scots law, but such authority as there is seems to point in that direction. Cumbernauld and Kilsyth DC v Dollar Land (Cumbernauld) $\mathrm{Ltd}^{87}$ was a case concerning the alleged creation of a public right of way through a walkway in the centre of the town of Cumbernauld. This walkway had originally belonged to Cumbernauld Development Corporation, and had then subsequently belonged to the defenders. The walkway had been widely used by the public over many years to gain access to the town centre, but the defenders then decided to close the

\footnotetext{
${ }^{86} \mathrm{We}$ are concerned, of course, only with my actions after the permission was given. If I took up occupation of the property before the permission, that act was nonetheless unlawful at the time, regardless of the permission subsequently given.

871992 SC 357.
} 
walkway at night out of concern about anti-social behaviour. The local authority sought to prevent this, claiming that a public right of way existed through the walkway.

To establish this claim, the local authority had to demonstrate that the route had been possessed as a public right of way 'for a continuous period of twenty years openly, peaceably and without judicial interruption'. ${ }^{88}$ Use that was by the owner's tolerance would not be enough. ${ }^{89}$ Rather, the use had to be as of right. The defenders accordingly argued that the public's use had been by the tolerance of them and the Development Corporation as their predecessors in title. The Lord President summarised the defenders' argument in this way:

Much was made of the special character of the development corporation as a corporation with statutory responsibility for the laying out and development of the new town. It was said that they had a responsibility to promote the use of the segregated route as a means of access to the town centre and to allow through traffic on that route. Unlike a private landowner, who would have had a competing interest to that of the public, their interest was to encourage its use by the public. Since they had no obvious interest to exclude the public, their inaction in that regard should not be ascribed to acquiescence in its use by the public as of right, but to tolerance of a use which was consistent with their policy. ${ }^{90}$

The similarity of this approach to the 'heresy' of Bramwell LJ in Leigh v Jack, noted above, will be obvious. This argument was, however, rejected. It is clear that possession in the context of prescriptive acquisition is judged objectively, according to what people actually do and say, and whether I possess is not determined by what someone else may have thought about it. At most, that can only be part of the surrounding circumstances by which my intentions are judged. At heart, the question is what the person claiming to possess has done. For present purposes, the importance of this case is captured in two comments from the Lord President's opinion. First:

\footnotetext{
${ }^{88}$ Prescription and Limitation (Scotland) Act 1973, s. 3(3).

${ }^{89}$ See Lord Rodger in $R$ (on the application of Beresford) $v$ Sunderland City Council [2003] UKHL 60; [2004] 1 AC 889 for comment on differing Scots and English approaches to tolerance in the context of prescriptive acquisition.

901992 SC 357, at p. 363.
} 
If his position is to be that the user is by his leave and licence, he must do something to make the public aware of that fact so that they know that the route is being used by them only with his permission and not as of right. ${ }^{91}$

And again:

a proprietor who allows a way over his land to be used by the public in the way the public would be expected to use it if there was a public right of way cannot claim that that use must be ascribed to tolerance, if he did nothing to limit or regulate that use at any time during the prescriptive period. ${ }^{92}$

Although obiter as regards the present point, these passages are strongly supportive of the idea that effect will be given to a unilateral permission in interrupting prescriptive acquisition. They certainly contain nothing to the contrary, and in the second passage the words 'if he did nothing to limit or regulate that use at any time during the prescriptive period' seem to assume that this is the case. This is no rogue case. We see something very similar in an earlier case, Marquis of Bute v McKirdy \& McMillan. In that case, also a public right of way case in which it was claimed that use had been by tolerance, it was said:

If the public user is of that degree and quality [for positive prescription to operate], the proprietor, who fails for the prescriptive period to assert or to put on record his right to exclude the public, must be taken to have remained inactive, not from tolerance, but because the public right could not have been successfully disputed or because he acquiesced in it. ${ }^{93}$

This again assumes that tolerance may be expressed at any time during the prescriptive period.

I hope that I have shown that the position of giving effect to a unilateral permission is not unreasonable and is not contrary to principle, and is probably the position of Scots law. Let us now think about the consequences of unilateral permission being held to be ineffective in interrupting prescriptive acquisition. A decision to that effect would have been helpful to

\footnotetext{
911992 SC 357 , at p. 366.

921992 SC 357, at p. 368.

931937 SC 93, at p. 120 (Lord President Normand).
} 
Molyneaux in the particular case, but what about future occupiers in similar cases? In real life, people often carry on their affairs with a good deal less formality than lawyers would consider ideal, with unspoken assumptions about the nature of the relationships being created, and many issues that we would consider essential left altogether unconsidered. This is far from ideal, but there is no helping it. People who anticipate continued cordial relationships will act in this way, without any thought for what will happen if relationships break down, and they will continue to do this whatever we say. The law has to be able to deal with this. From a common sense perspective, there was nothing unreasonable in the Smiths giving a unilateral permission, and then assuming that that permission represented a mutual understanding with Molyneaux. A reasonable bystander would have assumed that, if Molyneaux had a different understanding of the situation, he would have said or done something to indicate that. It is true, of course, that the assumptions of reasonable bystanders cannot be conclusive of what the law should be. There will often be compelling reasons to adopt a different rule or standard of conduct. Equally, though, the law should be slow to impose on individuals requirements that run contrary to those reasonable assumptions, unless there are good grounds for doing so. Here, if anything, the equities of the situation seem to run in the other direction. There has already been mentioned above one of the justifications for the nemo mutare potest rule, that without it the owner of land would have to be more active in enforcing his or her rights. Suppose that I own an area of land, which is being occupied in circumstances like those in Smith v Molyneaux. If Smith v Molyneaux had been decided the other way, I would be likely to consider that, if I could not get the occupier to enter into a formal agreement for continued occupation, my only option would be to remove the occupier. Litigation is sometimes necessary, but it is generally best avoided where possible. Litigation is expensive, time-consuming and unpredictable, but even if the occupier left voluntarily, requiring the occupier to leave would be to the benefit of neither of us: neither to my benefit, because the occupier's presence would be likely to limit deterioration of the property, nor to the occupier's benefit, for reasons that are obvious. The contrary rule is to my benefit, in allowing me to keep my rights alive when it suits me not to enforce them to their strict letter. ${ }^{94}$ Given that it is open to the occupier to reject the unilateral permission, there is no corresponding disadvantage to him or her other than the loss of the opportunity to acquire an unearned windfall by prescription. If we understand the purpose of prescription to

\footnotetext{
${ }^{94}$ A similar point is made Dillon LJ in BP Properties Ltd v Buckler (1988) 55 P \& CR 337, at p. 346.
} 
be not so much to benefit the acquirer, but to promote certainty of title, that is a loss that should be given little weight.

Finally, Oliver Radley-Gardner has suggested that, as a result of the decision in Smith $v$ Molyneaux:

landowners with squatters on land will take the precaution of issuing letters attempting to give unilateral permission for whatever use may be being made of the land in question pending proceedings in court. ${ }^{95}$

This is a real concern, but one that I would suggest may be exaggerated. Such a letter would be clearly enough sent, not with any genuine intention to give permission to occupy the land, but solely to interrupt the process of prescriptive acquisition. The courts are quite capable, I would suggest, of recognising such a clear sham and denying effect to it. Nothing here is meant to imply the contrary. Equally, in the typical case, if a genuine approach is made to the occupiers with a view to giving permission, it seems reasonable for the owner to be able to treat the occupation as being with his or her permission in the interim.

\section{Final comments}

I have tried here to look at the decision in Smith $v$ Molyneaux from the standpoint of Scots law. I hope to have shown that, proceeding from principles that are not at all dissimilar in our two jurisdictions, it is possible to reach different conclusions on the issue raised by Smith $v$ Molyneaux. Moreover, there are advantages in doing so. At the very least, I hope that this consideration has given some food for thought in examining the assumptions with which we approach issues of possession. I have not been able to escape the impression that the criticisms that have been aimed at the decision in that case assume parties that are at odds with each other unless they indicate otherwise. It is not clear to me that that is a better approach than presuming that parties who act in a manner consistent with the existence of an agreement are in fact in agreement. At its root, though, this may be a question of how objectively a person's intentions are to be judged. In Scots law, the answer has tended to be very much that possession is to be judged by objective standards. Other answers are possible.

95 O Radley-Gardner, 'Foisted Permission and Adverse Possession' (2017) 133 LQR 214. 
